\title{
Alfred Russel Wallace and the Darwinian Species Concept: His Paper on the Swallowtail Butterflies (Papilionidae) of 1865
}

\section{Alfred Russel Wallace y el Concepto Darwiniano de Especie: Su Trabajo de 1865 sobre Mariposas Papilio (Papilionidae)}

\author{
James Mallet ${ }^{1}$ \\ Galton Laboratory, Department of Biology, University College London, 4 Stephenson Way, London UK, \\ NW1 2HE \\ E-mail: j.mallet@ucl.ac.uk
}

\begin{abstract}
Soon after his return from the Malay Archipelago, Alfred Russel Wallace published one of his most significant papers. The paper used butterflies of the family Papilionidae as a model system for testing evolutionary hypotheses, and included a revision of the Papilionidae of the region, as well as the description of some 20 new species. Wallace argued that the Papilionidae were the most advanced butterflies, against some of his colleagues such as Bates and Trimen who had claimed that the Nymphalidae were more advanced because of their possession of vestigial forelegs. In a very important section, Wallace laid out what is perhaps the clearest Darwinist definition of the differences between species, geographic subspecies, and local 'varieties.' He also discussed the relationship of these taxonomic categories to what is now termed 'reproductive isolation.' While accepting reproductive isolation as a cause of species, he rejected it as a definition. Instead, species were recognized as forms that overlap spatially and lack intermediates. However, this morphological distinctness argument breaks down for discrete polymorphisms, and Wallace clearly emphasised the conspecificity of non-mimetic males and female Batesian mimetic morphs in Papilio polytes, and also in P. memnon, on the grounds of reproductive continuity. Finally, Wallace detailed how natural selection explains various forms of parallel evolution, including mimicry.
\end{abstract}

KEYwORDS: History of evolution, mimicry, species concepts, geographic variation, taxonomic inflation, island biology, Lepidoptera.

\section{RESUMEN}

Poco después de su retorno del archipiélago Malayo, Alfred Russel Wallace publicó uno de sus trabajos más relevante. En éste usaba mariposas de la familia Papilionidae como modelos para poner a prueba hipótesis evolutivas, e incluía una revisión de los Papilionidae de la región y la descripción de 20 nuevas especies. Wallace argumentó que los Papilionidae representaban las mariposas más avanzadas, opinión contraria a la sostenida por sus colegas, incluyendo Bates y Trimen, quienes pensaban que los Nymphalidae eran más avanzados debido a su posesión de patas vestigiales. En una sección muy importante, Wallace formuló lo que quizás constituye la más clara definición darwiniana de las diferencias entre especies, subespecies geográficas y "variedades" locales. También discutió la relación de estas categorías taxonómicas con lo que hoy se denomina "aislamiento reproductivo". Mientras aceptaba el aislamiento reproductivo como una de las causas del origen de especies, lo rechazó como una definición de especie. Por el contrario, las especies se reconocían como formas que se sobreponen espacialmente y carecen de intermedios. Sin embargo, este argumento basado en distinción morfológica falla ante la presencia de polimorfismos discretos. No obstante, basándose en continuidad reproductiva, Wallace claramente enfatizó la conespecificidad en Papilio polytes de machos no miméticos, hembras

${ }^{1}$ Written while a Fellow of the Wissenschaftskolleg zu Berlin, 2008-2009, and updated while a Helen Putnam Fellow of the Radcliffe Institute of Advanced Study, Harvard University, 2009-2010.

Pp. 42-54 en D’Elía, G. 2009. Una celebración de los aniversarios darwinianos de 2009. Gayana 73 (suplemento): 1-88. 
no miméticas y hembras miméticas batesianas; el mismo escenario planteo en P. memnon. Por último, Wallace detalló como la selección natural explica varias formas de evolución paralela, incluyendo el mimetismo.

Palabras clave: Conceptos de especie, biología de islas, historia de la evolución, inflación taxonómica, Lepidoptera, mimetismo, variación geográfica.

\section{INTRODUCTION}

In the early days of Darwinian evolutionary theory, natural selection was viewed as the main cause of the origin of new species. This view is again coming into fashion, after a rather long hiatus for most of the $20^{\text {th }}$ Century (Coyne \& Orr 2004; Price 2008; Schluter 2009). As is well known, the theory of natural selection first occurred to Alfred Russel Wallace during a bout of malaria on the island of Ternate, and his letter of 1858 on this topic to Charles Darwin was published by the Linnean Society alongside Darwin's own ideas. The idea of natural selection brought the theory of evolution into its modern, scientific age.

After returning to London from his travels in the 'Malay Archipelago' (as the islands of SE Asia were then known), Wallace addressed himself to the scientific understanding of his and Darwin's (1859) theories of evolution via natural selection. Wallace wrote a very important paper at this time, today all but forgotten, which is the main topic for the current article. In today's jargon, the title of Wallace's (1865) paper on Asian swallowtail butterflies would read something like "The Southeast Asian Papilionidae as a model system for the evolution of local varieties, geographic races, and species." This paper was originally read in 1864 at the Linnean Society. Wallace (1870) later reemphasised the "model system" aspects of the work when he republished an abridged version as "The Malayan Papilionidae or Swallow-tailed Butterflies, as Illustrative of the Theory of Natural Selection."

Many evolutionists existed previous to 1858 , but were primarily followers of Jean-Baptiste Pierre Antoine de Monet, Chevalier de Lamarck. Lamarck had a complex theory of evolution (Gillespie 1968, and see below). However, by 'Lamarckian' today we normally intend a belief that characters acquired during the lifetime of an individual can become inherited and are passed on to future generations.
Charles Darwin's own grandfather, Erasmus Darwin, was also an evolutionist in this mould. Another example of a Lamarckian evolutionist of this general persuasion was the anonymous author of "The Vestiges of Creation" (published in 1844, the author was later revealed to be Robert Chambers) ${ }^{2}$. Wallace read this work before embarking on his first tropical voyage to the Amazon with Henry Walter Bates.

Lamarck and his disciples clearly understood the evolutionary nature of species, but were unable to suggest very convincing mechanisms. Lamarck thought that evolution was constantly driven onwards and upwards via a kind of ladder of creation, with the supposedly more complex mammals, especially humans, at the top. A primary mechanism for evolutionary change was the yearning or "need" ("besoin") for progress, driven in part by the inheritance of acquired characteristics (Lamarck 1809). In this view, a giraffe's requirement for a longer neck to pull down ever higher branches would result in stretching of the neck, and the resulting longer neck was thought to be heritable by its offspring. Darwin consulted widely with breeders of animals and plants, and was forced by the evidence to conclude (apparently almost reluctantly), that this commonsense idea of inheritance of acquired characteristics was correct (Darwin 1859, 1875). In contrast, Wallace was convinced more by the simplicity and explanatory power of the idea of natural selection than by the abundance of erroneous data that clouded Darwin's beliefs, and he steadfastly

\footnotetext{
${ }^{2}$ Yet another early Lamarckian evolutionist was Robert Grant, who had met and probably influenced Darwin in Edinburgh, and who later became the first Professor of Zoology and Comparative Anatomy at the rebellious University of London. This was the first University in England where it was possible to study medicine, among other sciences; previously, only theology and the classics could be taught in England, due to the oppressive influence of the Church of England. This is why Darwin had to go to Scotland to study medicine (though he did not finish). It happens that the original University of London is the same institution on Gower Street, now called University College or UCL, which currently employs me. UCL was founded in about 1825; today, it is one of the three or four most important Universities in the United Kingdom.
} 
denied any importance to Lamarckism throughout his life. Arthur Stanley Eddington had not yet been born, so his excellent advice was not available, that "it is also a good rule not to put overmuch confidence in the observational results that are put forward until they have been confirmed by theory." As it turned out, Wallace was right to be suspicious. Inheritance of acquired characteristics can work, in a sense, for the transmission of human culture, but our knowledge of DNA and genetics indicates that such a mechanism is virtually impossible for physical characteristics, and essentially never contributes to genetic evolution in nature.

Natural selection, in contrast, provides a completely inanimate and naturalistic theory for evolution, which requires neither guidance by a deity, nor the teleological goal of "progress" suggested by Lamarck. This purely mechanistic view created many problems for the theory's initial acceptance, and indeed still does. However, in the long run, it also eventually led to a wide acceptance of the Darwin-Wallace evolutionary ideas by allowing evolution to be self-contained and free of dubious assumptions. Wallace's 1865 paper should be seen very much on this historical background. For Wallace, the important aim for this very long paper was to address the problem of species and the role of natural selection in their origin. Wallace's interest in collecting data to understand the evolution of species had indeed been central to the original plans he had made with Henry Walter Bates 18 years before, when they planned their earlier trip to the Amazon together (Bates 1863: Vol. 1, iii; Knapp 1999).

\section{BATES' PAPER ON MIMICRY IN SOUTH AMERICAN BUTTERFLIES AS A FORERUNNER}

Wallace's treatise on SE Asian swallowtail butterflies consists of a careful systematic revision of the Papilionidae, together with an extensive introductory section where he details the importance of these data for understanding local and geographic variation and the origin of species. It followed and seems closely modelled on the similar paper in the same journal by Henry Walter Bates. Bates (1862) wrote on the "Heliconidae" (consisting of heliconiine, danaine and ithomiine butterflies) of the Amazon basin.
Bates' paper, like Wallace's, consisted of a systematic revision, as well as a long introductory section about natural selection and the origin of species. Bates (1862), like Wallace, used a rather unprepossessing title: "Contributions to an Insect Fauna of the Amazon Valley. Lepidoptera: Heliconidae," which greatly disguises the importance of the paper. Today, this paper is chiefly recognized as the first to provide an evolutionary theory of mimicry which relied entirely on natural selection, a result admired by Darwin himself, who also expressed frustration at its burial in a long systematic paper with a cryptic title (Darwin 1863). See Mallet (2009a) for a brief commentary on Darwin's review of Bates' paper. Bates describes in particular how the colours of certain butterflies allied to the cabbage white butterflies, which he called "Leptalides" (now Pieridae: Dismorphiinae), copied local members of the "Danaoid Heliconidae" (now Danainae: Ithomiini) and "Acraeoid Heliconidae" (now Heliconiinae: Heliconiini). Wallace immediately understood and enthusiastically adopted Bates' theory of mimicry, which forms a major component of Wallace's paper. It seems to have been generally known before Bates that certain palatable flies, beetles and moths were imitators or mimics of stinging wasps, although mimicry had hitherto never been explained via natural selection. Bates's insights were far better documented than earlier ideas, and come from several special features he was the first to recognize in the Ithomiinae, Heliconiini and Dismorphiinae.

The first feature that Bates understood from his butterflies (as did Wallace) was the importance of geographic distribution in natural selection. Bates had not recognized mimicry before returning to London. As he began to pin out and examine his butterfly specimens, he describes how he suddenly noticed not just that nearly identical colour patterns were found in multiple unrelated species from the same area, but that the colour patterns of all these species or lineages would themselves switch every few hundred miles. This was as true for the multiple species of models in the Danaini and Ithomiini as for the copies or "mimics" in the Heliconiini and Dismorphiinae. Anyone who has captured Ithomiini or Heliconiini knows that most are clearly defended by pungent and noxious-seeming smells, and from this and their great abundance in the field Bates assumed they were protected from birds and other 
predators. Although Bates provided only anecdotal evidence for unpalatability based on observations of birds in the wild, later work has shown that he was absolutely correct (e.g., Brower et al. 1963; Chai 1986). Bates recognized that dismorphiine mimics were probably palatable, and today, where a palatable species parasitises the colour pattern of an unpalatable, protected species, we call the phenomenon Batesian mimicry in his honour. Bates also recognized that some rarer, unpalatable species, such as butterflies in the genus Heliconius, mimicked Ithomiini, with exactly the same geographic pattern of switching colours. He argued (probably correctly) that the rarer Heliconiini were protected by the commoner Ithomiini rather than vice-versa (Mallet 2001a), although he failed to understand why mimicry among pairs of extremely abundant species such as those in the genus Melinaea and Mechanitis could be favoured by natural selection.

Today, mimicry between pairs of unpalatable species is known as Müllerian mimicry, after Fritz Müller (1879), who provided a mathematical formulation of how mimicry between poisonous species was mutually favoured, and of how the benefits to each mimetic partner were split according to the inverse square of their relative abundance (Mallet 2001a). Although it is clear that Bates had discovered Müllerian mimicry already, this is not to belittle in any way the tremendous achievement of Müller, who was the first to clearly understand its mechanistic basis. Müller's paper was also the first to contain a mathematically reasoned theoretical argument in evolutionary biology (Joron \& Mallet 1998; Mallet \& Joron 1999).

Regardless of the type of mimicry, Bates understood the importance of parallel geographic switching of mimicry 'rings' of Ithomiini, Heliconiini and their mimics across the Amazon basin. This clearly and convincingly implicated natural selection. With dozens of species and lineages involved, and dozens of geographic switches, this comparative biogeographic evidence was the best evidence produced yet (and perhaps ever!) for the power of natural selection to affect variation in the wild. Wallace, as we shall see, completely agreed with Bates' deductions, and showed that mimicry and natural selection had had significant evolutionary and biogeographic effects elsewhere in the tropics.
The second major deduction of Bates concerned causes for the origins of species. Bates argued not only that natural selection for mimicry was the cause of geographic variation, but also that this geographic variation led ultimately to the evolution of new species. After geographic variation had given rise to new forms, they might ultimately disperse until they overlapped in the same region, whereupon one outcome is that they could coexist but remain separate. If the different forms did not intercross, the result would be the coexistence of two species. Bates seems to have believed that selection on mimicry could in some way influence mating behaviour; he wasn't very specific on mechanisms, but his 1862 paper suggests that he found examples in the genus Mechanitis of closely related forms with different colour patterns not mating together. His travel book (1863) also suggests that he found similar examples in co-existing Heliconius forms ${ }^{3}$. I believe that in some cases the poorly understood systematics of these groups had confused him, and that he in fact had found examples of widespread but highly confusing Mechanitis species that coexisted (Dasmahapatra et al. 2009), or of Heliconius melpomene or Heliconius erato with red and black postman patterns coexisting with other species of heliconiines such as Neruda aoede, Heliconius elevatus, and Heliconius demeter ${ }^{4}$.

Darwin (1863) urged Bates to provide more detail for his findings that colour varieties of these mimetic butterflies became reproductively isolated. As far as I know, Bates never did so. Instead, his later work concentrated chiefly on beetles and management of the Royal Geographical Society. Today, we know that Bates' idea was correct in broad outline for some Heliconiina: there are examples of closely related Heliconius species that differ in mimicry ring; these are able to remain separate species in part because their mating behaviour depends strongly on the colour pattern (Jiggins et al. 2001).

In any case, Wallace admired and frequently cited Bates' butterfly paper, and in 1865 he was able to greatly amplify its results, as well as add new

\footnotetext{
${ }^{3}$ However, this passage on the Origin of Species by Segregation of Local Varieties is found only in the two-volume first edition, specifically in Vol. 1, pp. 255-265. It was deleted from later 'popular' editions.

${ }^{4}$ This is not meant as a criticism of Bates, because we are still finding new, cryptic species in the Heliconiini and Ithomiini today.
} 
evidence of natural selection for mimicry. He also improved on understanding of the geographical nature of species in his Papilionidae paper.

\section{WALLACE'S MAJOR CONTRIBUTIONS IN HIS PAPILIONIDAE PAPER}

Wallace's 1865 paper is today perhaps even more misunderstood than Bates,' largely, I believe, because of its complexity, discursiveness, and length (71 quarto pages including a complete systematic revision and descriptions of around 20 new species, and additionally, eight plates of engravings, which were laboriously hand-tinted in published versions). Another reason is that Wallace himself later tended to underemphasize what I believe are major contributions of the paper to the understanding of species, because he increasingly became a journalist who had to write to survive; scientific ideas were inevitably of secondary concern compared with sales. Wallace published abridged versions of the evolutionary introduction to his paper in various forms, first in 1864 in "The Reader", and later as Chapter IV of his book "Contributions to the Theory of Natural Selection" (1870), both of which specifically omit the arguments on species, as well as the taxonomic revision.

Wallace's Argument For The Papilionidae As The Most Advanced Butterflies

Wallace starts out by arguing that butterflies provide an excellent group for testing theories of evolution, and then discusses whether Papilionidae are most 'advanced' butterflies. There seems to have been some friendly banter amongst Darwinists about which was the top group of butterflies. Bates (1862) started the ball rolling by arguing that the "heliconids" (i.e., Ithomiini and Heliconiini) were most advanced, because, in company with the rest of the Nymphalidae (using today's nomenclature, including Danainae, Morphinae, Brassolinae, Satyrinae, etc.), they have extremely reduced forelegs. Most Lepidoptera have three pairs of fully functional legs, but there is progressive diminution of the size of the forelegs in certain butterflies, particularly the Lycaenidae, Riodinidae, and Nymphalidae, in the latter of which the Ithomiini and Heliconiini belong.
Wallace rejects Bates's argument on the grounds that mere degeneration of organs cannot be used to measure advancement. In contrast, Wallace argues that the four-branched median wing vein, and Y-shaped "osmeterium" thoracic organ in papilionid caterpillars are true signs of advancement in the Papilionidae, indicative of novel additional traits or organs not present in other groups. A few years later, Roland Trimen (1869) rejected Wallace's arguments, arguing that his own favourites, the Danaini are in fact the most advanced. However, Wallace (1870) reissued his 1865 paper and was thereby able to have the last word. In a revised section, he rebutted Trimen's assertions, one by one. Trimen had argued that the reduction of limbs was indeed an advance because this led the butterflies to be more "aerial." Wallace (1870) felt that the argument that the most aerial butterflies were most advanced would also mean that swifts and frigate birds were more advanced than song birds; however "no ornithologist has ever so classified them." Instead Wallace argued that one of three groups of birds with highly developed feet -falcons, parrots, or thrushes and crows- had greater claim to be the most advanced. Wallace (1870) again supported the Papilionidae, with their perfect forelegs, as the most advanced butterflies.

In retrospect this argument is more amusing than informative: today, evolutionary biologists agree that since all extant groups have evolved and been tested by natural selection for exactly the same period of time since divergence from a common ancestor, there is no objective way to decide which groups are more 'advanced.' Nonetheless, the Papilionidae are often the group of butterflies treated first in typical books, even today (e.g., Scott 1986; Larsen 1991; Tolman \& Lewington 1997), so perhaps Wallace's argument had some effect. On the other hand, R.I. Vane-Wright informs me (pers. comm.) that another reason for including the Papilionidae at the head of the butterflies may be that they are the most ancient lineage in the Papilionoidea. In essence, this is to argue the reverse: that the swallowtails are in a sense the most 'primitive.'

Papilionidae, Reproductive Isolation And The Evolution Of New Species

An important evolutionary part of the paper now begins. Here Wallace outlines his view of species, 
and the various kinds of variation below the species level. "What is commonly called variation consists of several distinct phenomena which have too often been confused." Today's evolutionary biologists rarely read Victorian texts and often believe that Darwin and the Darwinists of the 1850s and 1860s were confused about species (Mayr 1982; Coyne \& Orr 2004). According to these modern commentators, Darwin (1859) did not understand the nature of species, and therefore didn't answer the question posed by the title of his book ("On the Origin of Species"). For critiques of these views see Mallet (2004, 2008a,b, 2009b). Darwin discussed what he meant by species, of course, but he did not describe the different kinds of variation at the subspecific level in a systematic way, especially when dealing with geographically distant populations. Most people can recognize species when they coexist (i.e., in "sympatry"), but the eternal problem in taxonomy is how to treat differentiated forms that occur in different areas (i.e., in "allopatry"), since the test of coexistence is not available.

I believe Wallace's paper utterly rebuts the notion that early Darwinists had a poor understanding of the nature of species. Wallace gives a long discussion of geographic and non-geographic variation, and carefully distinguishes species from geographic races and local varieties or forms. He distinguishes: " 1 st, simple variability [equivalent to quantitative variation]; 2nd, polymorphism or dimorphism [discrete forms separated by morphological gaps, which nonetheless belong to the same species]; $3 \mathrm{rd}$, local forms or varieties [clinal variation]; 4 th, coexisting varieties ... a somewhat doubtful case [reserved for coexisting forms which differ in very few constant characters, but which seem to be separate species; 'sibling species' or 'ecological races' perhaps would be the modern equivalent]; 5th, [geographic] races or subspecies; and 6th, true species" (Wallace 1865: 5-14). As far as I know, this is the first attempt by a Darwinist to enumerate and classify the geographical and non-geographical "varieties" that Darwin argued were the forerunners of species: the lack of a detailed discussion by Darwin is exactly what prompted Mayr (1942, 1963, 1982) and followers to accuse Darwinists of having failed to produce an adequate species definition. In fact, Darwin, as well as Darwinists such as Wallace and Bates, understood the nature of species very well, even in modern terms (Mallet
2004, 2009b). Darwin himself, in what he always intended only as a brief "abstract" (1859) did not discuss species definitions in great detail. As a result, this 1865 paper of Wallace's is perhaps the best statement of the party line by an early Darwinist of what was meant by species, and of how local and geographic variation within species was to be distinguished from that at the species level. Wallace's (1865) discussion is an important forerunner of similar discussions of geographic and non-geographic variation by Walter Rothschild and Karl Jordan (1895) as well as by Edward Bagnall Poulton (1904). All three were informed by extensive knowledge of variation in Papilio butterflies, and they were in their turn among the most important influences on the species concept of Mayr and others (see Mallet 2004). The main point of Wallace's argument is to show that it is hard to distinguish species from geographic subspecies, unless they overlap and show few intermediates.

Wallace, like Darwin, agrees that species are typically reproductively isolated but is inclined to reject a simple-minded application of the idea of reproductive isolation as a definition. His grounds are first that reproductive isolation was an impractical definition. Second, while reproductive isolation is a cause of speciation, it cannot also serve as a criterion of species: "Species are merely those strongly marked races or local forms which, when in contact, do not intermix, and when inhabiting distinct areas are generally regarded to have had a separate origin, and to be incapable of producing a fertile hybrid offspring. But as the test of hybridity cannot be applied in one case in ten thousand, and even if it could be applied, would prove nothing, since it is founded on an assumption of the very question to be decided -and as the test of origin is in every case inapplicable- and as, further, the test of non-intermixture is useless, except in those rare cases where the most closely allied species are found inhabiting the same area, it will be evident that we have no means whatever of distinguishing so-called 'true species' from the several modes of variation here pointed out, and into which they so often pass by an insensible gradation" (Wallace 1865: 12). Perhaps if this argument together with Darwin's proposal that "hybridism" should not be used as a hard-and-fast definition of species had been generally accepted, we could have seen a smooth transition from Darwinian thought to 
today's genetics-based understanding of evolution (Mallet 2008a). However, it was not to be, and there are now many fruitless arguments about species definitions that distract attention from other more pressing problems in taxonomy, biodiversity and conservation (Hey 2001; Coyne \& Orr 2004; Isaac et al. 2004).

Reproductive Isolation And Sex-Limited Mimicry PolymorphisM

The extraordinary sex-limited mimicry polymorphisms of butterflies such as Papilio memnon and Papilio polytes were important in leading Wallace to his view of sympatric species. Wallace (1865) was the first to collate evidence for female-limited polymorphism and mimicry in Papilio, especially for the Asian species we now call Papilio memnon, P. polytes, and P. aegeus. Many of the female forms are Batesian mimics of different unpalatable species, although some are non-mimetic, and resemble the males. Wallace's lumping of such diverse forms into single species relied on detailed morphological comparisons of traits not involved in mimicry or sex-differences, unification of pairs of "species" where only males were known with others only known as females (e.g., P. polytes, P. 'pammon'), breeding data -individuals emerging from eggs laid by a single female- and from observations of pairs in copula. Wallace cites his own observations as well as published work and correspondence. A revealing citation is to a paper published by Benjamin D. Walsh in 1863. Walsh was an Englishman living in Pennsylvania, and yet another correspondent of Darwin's. Walsh was the first to show that the black form Papilio glaucus was conspecific with the yellow P. turnus in the Proceedings of the Entomological Society of Philadelphia. Later in the same year and journal, Walsh proposed his own species concept in relation to interbreeding (Walsh 1863: 220; see also Berlocher \& Feder 2002). The common topics of Walsh's and Wallace's papers in these few years after the publication of 'The Origin' argue, again, that the consensus on definition of species by these scientists (Mallet 2008b) was not coincidental, but due to a constant flow of information among Darwinists tackling similar problems, not just within the UK, but also internationally.

Wallace (1865: 10-11, footnote) imagines the situation if Papilio-like genetics were found among humans: "The phenomena of dimorphism and polymorphism may be well illustrated by supposing that a blue-eyed, flaxen haired Saxon man had two wives, one a black-haired, red-skinned Indian squaw, the other a woolly-headed, sooty-skinned negress -and that instead of the children being mulattoes of brown or dusky tints, ... all the boys should be pure Saxon boys like their father, while the girls should altogether resemble their mothers. ... Yet the phenomena ... in the insect world are still more extraordinary; for each mother is capable not only of producing male offspring like the father, and female like herself, but also of producing other females exactly like her fellow-wife, and altogether differing from herself."

Needless to say, this new Darwinian view that a species could contain such diverse forms was highly controversial for a while among butterfly systematists. When Trimen (1869) established that multiple female mimetic forms in Africa were members of the same species as male Papilio merope swallowtails, because they mated together (today, all are included in Papilio dardanus), the creationist William Chapman Hewitson expressed horror: “... I am quite incapable to believe that ... P. merope ... indulges a whole harem of females, differing as widely from it as any other species in the genus." These ideas were but "the childish guesses of the Darwinian school" (Hewitson in Poulton 1904: Ixxxvii).

\section{Splitting vs. Lumping Of Geographical Replacement FORMS}

Wallace's view that interbreeding, sympatric, polymorphic forms were members of the same species is today quite uncontroversial. However, he also tackles the much more difficult problem of which allopatric forms to call species, and which to call geographic races. Wallace employs a pragmatic definition of species, i.e.: "the only distinction between species and well-marked varieties is, that the latter are known, or believed, to be connected at the present day by intermediate gradations" (Darwin 1859: 485). But what to do about the forms isolated on different islands in the Malay Archipelago, where intermediate gradations could not occur because of the absence of a land connection? "The rule ... that I have endeavoured to adopt is, that when the difference between two forms inhabiting separate 
areas seems quite constant, when it can be defined in words, and when it is not confined to a single peculiarity only, I have considered such forms to be species. When, however, the individuals of each locality vary among themselves, so as to cause the differences between the two forms to become inconsiderable ... I class one of the forms as a variety of the other" (Wallace 1865: 4).

Wallace touches here on a problem that has bedevilled application of the biological species concept since its inception. Mayr (1963: 29-30) highlights "the importance of a non-arbitrary definition of species", but also agrees that, in practice, some arbitrariness is unavoidable for forms that are not in geographic contact: "It cannot be denied that an objective delimitation of species in a multidimensional system [i.e., over large expanses of space or time] is an impossibility" (Mayr 1963: 13). A solution like Wallace's is a practical necessity in this situation and it seems to me that the Darwinian decision he did make about allopatric forms wasn't as fatal to the understanding of speciation as Mayr and his followers have claimed.

Examining the actual ranks that Wallace uses in his revision suggests that he tended to split species geographically somewhat more than today's butterfly systematists, especially in very brightly coloured and geographically variable groups. Wallace argues that the Malayan region is richer in Papilionidae than any other tropical region on the planet. However, "this superior richness is partly real and partly apparent. The breaking up of a district into small isolated portions, as in an archipelago, seems highly favourable to the segregation and perpetuation of local peculiarities in certain groups ... From this point of view, therefore, the superior number of Malayan species may be considered as apparent only. Its true superiority is shown, on the other hand, by the possession of three genera and twenty groups of Papilio against a single genus and eight groups in South America, and also the much greater size of the Malayan species" (pp. 27-28). Today, there are considered to be 10 genera of Papilionidae in the neotropics, as compared to S.E. Asia, considered also to have around 10 genera among the taxa treated by Wallace here. Furthermore, "much greater size" doesn't seem such a major claim on superiority as it may have seemed to Wallace. We are left with the idea that perhaps most of the greater diversity of Malay Archipelago is "apparent."

In part, Wallace's inflation of S.E. Asian species diversity stems from the practical species concept he adopted. He often recognized disjunct forms on different islands as closely related members of the same lineages, but nonetheless classified them as separate species "when the difference between two forms inhabiting separate areas seems quite constant, when it can be defined in words, and when it is not confined to a single peculiarity only". Thus, he classified as separate species what are now considered three subspecies of the 'gloss swallowtail' Papilio ulysses from different islands, on the grounds of strong morphological differences. For the New Guinea form penelope Wallace (= Papilio ulysses autolycus Felder), he argues: "As all the other forms closely allied to $P$. Ulysses have received names (Telemachus, Montr., Chaudoiri, Feld., Telegonus, Feld., and Ulyssinus, Westw.), I have also given one to this form peculiar to New Guinea and the Papuan Islands, the distinctive characters of which, though very slight, seem sufficiently constant" (p. 44). Similarly, several of the forms recognized as species by Wallace among the showy birdwing butterflies (Ornithoptera), are today regarded as subspecies.

Wallace could himself have recognized such obvious 'replacement forms' as subspecies. However, in the 1860s, there was no International Commission of Zoological Nomenclature, and no recognized rules for distinguishing names of clearly demarcated subspecies from those referring to local sports and variants -all were subsumed within infraspecific 'varieties.' Today, names described as 'varieties' or 'forms' are no longer admitted as valid in zoology, while geographic 'subspecies' names are considered to belong to the 'species group names' category and remain valid. Wallace felt that, if described merely as varieties, these important geographically differentiated taxa would be forgotten: in order to make sure that they were recognized as distinct, he felt he had to classify them as species. "Varieties ... continually get overlooked; in lists of species they are often altogether unrecorded; and thus we are in danger of neglecting the interesting phenomena of variation and distribution which they represent.

\footnotetext{
${ }^{5}$ A recent study has shown that the most diverse area of the world for Papilionidae is in the border region of NE India; see Haüser et al. 1995.
} 
I think it advisable, therefore, to name all such forms [i.e., as separate species]; and those who will not accept them as species may consider them as subspecies or races" (p. 12).

Wallace is here frankly admitting to taxonomic inflation, but in a good cause: in order to make sure that the forms are recognized as being on the speciation spectrum, even if future authors do not recognize them as full species (as is today the case). He did this quite openly, according to his criteria, given above, in order to draw other systematists' attention to the distinctness of the local forms that he names as a separate species. In the late $19^{\text {th }} \mathrm{C}$. and early $20^{\text {th }} \mathrm{C}$., the problem that very well-marked geographic varieties were either not being recognized at all, or alternatively had to be recognized as dubious separate species, led to butterfly and bird systematists introducing the trinomial Linnaean nomenclature (Mayr 1942, 1963, 1982; Stresemann 1975; Rothschild 1983; Mallet 2001b, 2007), whereby geographic subspecies could receive formal names. Indeed, one of the first major works to formalize this system of polytypic species and trinomial nomenclature was that by Rothschild [\& Jordan] (1895) on the Papilionidae. That major revision can clearly be seen to be built on the foundation of Wallace's paper reviewed here.

Overall, we can assess Wallace's work on species as follows. He well understood the spectrum of divergence between varieties and species, and after his extensive travels, the Papilionidae provided him with ample material to understand geographical variation and geographical speciation. From the evidence just presented, he clearly understood that he was inflating the importance of certain related forms found on different islands as separate species, but he frankly admitted the arbitrariness of his approach, just as did Mayr (see above). Wallace's practical approach is in fact somewhat similar to the diagnostic delimitation of species as practised by followers of Joel Cracraft (1989), an approach which has led to a great deal of recent taxonomic inflation among the vertebrates (Isaac et al. 2004), and which is also beginning to affect butterfly nomenclature (e.g., Tolman \& Lewington 1997).

Although Wallace can perhaps be criticized with hindsight as a splitter of geographically identifiable subspecies into species, as a pioneer he surely has some right to make a few mistakes. He was, after all, the very first to make a detailed study on the topic of species delimitation and geographic variation in a post- 1859 context. Reading the text carefully, I am continually impressed by how enlightened he appears, even compared to many of today's taxonomists. We should not forget that he wasn't working with 2009 knowledge, he was in fact the original developer of the ideas that later came to be used in Papilionidae and other butterflies, particular by Walter Rothschild, Karl Jordan and others. In fact, Wallace's (1865) and Bates's (1862) papers together were the first stabs at species delimitation in natural systems that clearly acknowledged an evolutionary framework (see also Mallet 2004).

\section{Parallel Evolution}

The final topic I would like to cover is the topic that, perhaps for Wallace, was the most important goal, and that was to collate geographic evidence for natural selection, and its involvement in speciation. This evidence is covered in two sections, entitled "Variation as specially influenced by Locality" (pp. 14-19), and "Mimicry" (pp. 19-22).

In the former section, Wallace notices some patterns which are rather baffling, and which still have not been explained, to my knowledge. "I find that larger or smaller districts, or even single islands, give a special character to the majority of their Papilionidae. For instance: 1. The species of the Indian region (Sumatra, Java, and Borneo) are almost invariably smaller than the allied species inhabiting Celebes and the Moluccas; 2 . The species of New Guinea and Australia are also, though in a less degree, smaller than the nearest species or varieties of the Moluccas; 3 . In the Moluccas themselves, the species of Amboyna are the largest; 4. The species of Celebes equal or even surpass those of Amboyna; 5. The species and varieties of Celebes possess a striking character in the form of the anterior wings, different from that of the allied species and varieties of all the surrounding islands; 6. Tailed species in India or the Indian region become tailless as they spread eastward through the archipelago" (p. 14). The "striking character of the anterior wings" mentioned was that the forewing is often more falcate (i.e., almost forked), and/or that the costa (i.e., the forewing anterior margin) is more abruptly curved. Wallace cites some 16 Celebes [i.e., 
today's Sulawesi] species in 9 groups of Papilio with these characters enhanced, as compared with allied species from surrounding islands, and figures the curvatures of the wings in line drawings of 6 pairs of species in Plate 8 of Wallace (1865). He also argues that the same is true for some 10 species of Pieridae and some other examples from the Nymphalidae.

"The facts now brought forward seem to me to be of the highest interest" (p. 17), but what could be the explanation? The only papilionids which do not show this Celebes effect are the Aristolochia-feeding group now included in the Troidini, and which are frequently the objects of mimicry by Papilio. Wallace correctly assumes that the troidines are protected from predators, "probably in a peculiar odour or taste". In contrast, the other Papilio do not get such protection, and Wallace argues: "the arched costa and falcate form of wing [found in the Papilio of Celebes] is generally proposed to give increased powers of flight, or, as seems to me more probable, greater facility in making sudden turnings, and thus baffling a pursuer. ... It would thus appear as if there must be (or once have been) in the island of Celebes, some peculiar enemy to these larger-sized butterflies which does not exist, or is less abundant than in the surrounding islands" (p. 18). In spite of his travels, Wallace cannot come up with such an enemy, although he toys with ideas that it could be a bird or one of the larger dragonflies.

Plate 8 of Wallace (1865) clearly shows the curved character of the Celebes wings, and their relative sizes. As far as I know, this rather puzzling effect of parallel evolution seems to be correct, and has never been reinvestigated with modern methods (VaneWright \& de Jong 2003). Rather than depicting the average size, Wallace chose the largest specimens from each island to make these claims, presumably to avoid the problem that a few adults in most butterfly populations are dwarfed by starvation as larvae when they eat up their whole foodplant; but still, a proper statistical analysis is surely required. In retrospect, I wonder whether the larger size of the Celebes butterflies are the cause of the more abruptly curved costa and the more falcate wing tip; it would be easy to imagine the latter happening as a correlated effect of the extra growth on Celebes and Amboyna. In any case, even the size alone would provide powerful evidence of parallel evolution on Celebes. Dwarfism and gigantism on islands vs. mainlands has long been recognized in vertebrates, and is the subject of much debate even today (e.g., Case 1978; Lomolino 2005; Raia \& Meiri 2006), and so a reinvestigation of the Celebes phenomenon in the Papilionidae would be of extreme interest. The Papilionidae and butterflies in general could provide much more powerful evidence of parallel evolution because of the much higher degree of replication in this group than in mammals, birds or reptiles.

Assuming Wallace's analysis is correct, he is way ahead of his time in pointing to this kind of parallel evolution as strong evidence for natural selection. If many different lineages independently evolve in a single direction, this is the best comparative evidence that natural selection, rather than random factors, is involved in producing the result. Today, parallel speciation is one of the strongest arguments for speciation by ecological causes (Schluter \& Nagel 1995); the argument is precisely of the same kind as that used by Bates and Wallace.

The second topic which provides evidence for local natural selection and parallel evolution is of course mimicry. We have already mentioned Wallace's evidence that Batesian mimicry explained the multiple female forms of species such as Papilio memnon, Papilio polytes, and others. These female forms all mimic protected members of the Aristolochia-feeding Troidini (at that time also included within the genus Papilio). Wallace also recognizes mimicry between palatable Papilionidae and unpalatable Danainae: that Papilio (= Chilasa) paradoxa and relatives mimicked a variety of Euploea, that Papilio (= Graphium) thule mimicked members of the genus 'Danaus' (= Parantica and Ideopsis), and that Papilio (= Graphium) idaeoides and others mimicked Hestia (=Idea) spp. Finally, he was also clear that a local form, Papilio (aegeus) pandion mimicked the protected Drusilla (=Taenaris) bioculat $[u s]$ in the Morphinae.

Wallace furthermore discusses why mimicry in some pairs of species should so often favour the female. He explains this partly by Darwin's hypothesis of sexual selection - the male pattern seems more conservative in this group, maybe a result of conservative female preference - and partly due to different habits of the males and females. Males are not so laden with eggs, and can therefore evade predators better, and so do not 'require' 
mimicry. Thus, according to Wallace at this time, sexual dimorphism in these groups was explained partly by Darwinian sexual selection, and partly by natural selection sensu stricto affecting adaptive coloration of males and females differentially. This contrasts with his later rejection of Darwinian sexual selection via female choice (Wallace 1889) ${ }^{6}$. All of these cases demonstrated that the Papilionidae of the region "have undergone an amount of special adaptive modification rarely equalled among the more highly organized animals" (p. 22). Once again, the extraordinary parallel geographic variation in mimicry between unpalatable model species and all of their mimics in the Papilionidae is an extremely strong argument for natural selection.

\section{CONCLUSION}

This 1865 paper is perhaps the pinnacle of Wallace's empirical achievement in original science. In it, he describes more species than in any of his other systematic works. He lays out the groundwork for today's theories of species and speciation, and distinguishes between geographic and nongeographic varieties (including geographic races and subspecies) and species. And he produces some of the best replicated evidence for the power of natural selection to affect, not just single species, but whole groups of species at a time in terms of size, wing shape, and mimicry.

Wallace's paper also clearly demonstrates that Darwinists in the decade following the publication of 'the Origin' had a clear understanding of the nature of species (Mallet 2008b); it is difficult to sustain the frequent modern criticism (e.g., Mayr 1982; Coyne \& Orr 2004) that Darwin and his followers misunderstood species, and that a better understanding had to wait until the mid $20^{\text {th }}$ Century. Quite to the contrary: today's evolutionary view of species, including Mayr's biological species concept, stem in part from this very paper of Wallace's, via Poulton, Rothschild, and Jordan, who all worked on the Papilionidae and had read Wallace's work carefully (Mallet 2004). In addition, Wallace was a much more engaging writer than either Darwin or Bates: the paper is still a delight to read, and it

${ }^{6}$ See also Andrew Berry's extracts from Wallace's writings, and his careful discussion of the sexual selection issue between Darwin and Wallace (Berry 2002). is spiced with many extraordinary phenomena that bear further examination with today's modern tools of science, such as genetics and statistics.

\section{ACKNOWLEDGMENTS}

I am extremely grateful to George Beccaloni, Guillermo D'Elía and Dick Vane-Wright for carefully reading the text. They helped to correct errors of fact and butterfly nomenclature. I am also grateful to the Wissenschaftskolleg zu Berlin and the Radcliffe Institute for Advanced Study, Harvard University, for their kind hospitality and sabbatical fellowships. Our sympatric speciation Schwerpunktgruppe in Berlin, consisting of Axel Meyer, Patrik Nosil, Francisco Úbeda de Torres, and Jeff Feder, provided a pleasant working environment in which to work. This article is a version of an introduction to the possible re-issue of Wallace's (1865) paper.

\section{BIBLIOGRAPHY}

Bates, H. W. 1862. Contributions to an insect fauna of the Amazon valley. Lepidoptera: Heliconidae. Transactions of the Linnean Society of London 23:495-566.

Bates, H. W. 1863. A Naturalist on the River Amazons. John Murray, London.

Berlocher, S. H. \& J. L. Feder, 2002. Sympatric speciation in phytophagous insects: moving beyond controversy? Annual Review of Entomology 47:773-815.

BERRY, A. 2002. Infinite Tropics: an Alfred Russel Wallace Anthology. Verso, London.

Brower, L. P., J. V. Z. Brower, \& C. T. Collins. 1963. Experimental studies of mimicry. 7. Relative palatability and Müllerian mimicry among Neotropical butterflies of the subfamily Heliconiinae. Zoologica, New York 48:65-84.

Case, T. J. 1978. General explanation for insular body size trends in terrestrial vertebrates. Ecology 59(1):1-18.

CHAI, P. 1986. Field observations and feeding experiments on the responses of rufous-tailed jacamars (Galbula ruficauda) to free-flying butterflies in a tropical rainforest. Biological Journal of the Linnean Society 29(3):166-189.

Coyne, J. A. \& H. A. Orr, 2004. Speciation. Sunderland, Sinauer Associates, Massachusetts.

Cracraft, J. 1989. Speciation and its ontology: the empirical consequences of alternative species concepts for understanding patterns and processes of differentiation. In: Speciation and its Consequences (Eds. Otte, D. \& J. A. Endler), 
pp. 28-59. Sinauer Associates. Sunderland, Massachusetts.

DARWIN, C. 1859. On the Origin of Species by Means of Natural Selection, or the Preservation of Favoured Races in the Struggle for Life. John Murray, London.

Darwin, C. 1863. A review of H.W. Bates' paper on "mimetic butterflies". In: The Collected Papers of Charles Darwin (Ed. Barrett P.H.), pp. 87-92. University of Chicago Press, Chicago.

DARWIN, C. 1875. The Variation of Animals \& Plants under Domestication. John Murray, London.

Dasmahapatra, K. K., M. Elias, R. I. Hill, J. I.Hoffmann \& J. MALLET. 2009. Mitochondrial DNA barcoding detects some species that are real, and some that are not. Molecular Ecology Resources 9 (available online doi: 10.1111/j.1755-0998.2009.02763.x).

Gillespie, C. C. 1968. Lamarck and Darwin in the history of science. In: Forerunners of Darwin: 1745-1859 (Eds. Glass, B. O. Temkin \& W. L. Straus), pp. 265-291. Johns Hopkins Press, Baltimore.

HÄuser, C. L., C. R.Smith \& R. I. VANE-Wright, 1995 Biodiversity, systematics, and conservation: a case study of swallowtail butterflies (Lepidoptera: Papilionidae). Verhandlungen der Deutschen Zoologischen Gesellschaft 88:148-161.

Hey, J. 2001. Genes, Categories, and Species. The Evolutionary and Cognitive Causes of the Species Problem. Oxford University Press, New York.

IsaAC, N. J. B., J. Mallet \& G. M. Mace, 2004. Taxonomic inflation: its influence on macroecology and conservation. Trends in Ecology \& Evolution 19(9):464-469.

Jiggins, C. D., R. E. Naisbit, R. L. Coe \& J. Mallet. 2001. Reproductive isolation caused by colour pattern mimicry. Nature 411(6835):302-305.

Joron, M. \& J. Mallet, 1998 Diversity in mimicry: paradox or paradigm? Trends in Ecology \& Evolution 13(11):461-466.

Knapp, S. 1999. Footsteps in the Forest. Alfred Russel Wallace in the Amazon. The Natural History Museum, London.

Lamarck, J.-B. 1809. Philosophie Zoologique. Dentu, Paris.

Larsen, T. B. 1991. The Butterflies of Kenya and their Natural History. Oxford University Press, Oxford.

Lomolino, M. V. 2005. Body size evolution in insular vertebrates: generality of the island rule. Journal of Biogeography 32(10):1683-1699.

Mallet, J. 2001a. Causes and consequences of a lack of coevolution in Müllerian mimicry. Evolutionary Ecology 13(7-8):777-806.

Mallet, J. 2001b. Subspecies, semispecies, and superspecies. In Encyclopedia of Biodiversity (Ed. Levin S. A.), pp. 523-526. Academic Press, San Diego.

Mallet, J. 2004. Poulton, Wallace and Jordan: how discoveries in Papilio butterflies initiated a new species concept 100 years ago. Systematics and Biodiversity 1(4):441-452.
Mallet, J. 2007. Subspecies, semispecies, superspecies. In: Encyclopedia of Biodiversity (Ed. Levin S. A.), pp. 1-5. Elsevier, Oxford.

Mallet, J. 2008a. Mayr's view of Darwin: was Darwin wrong about speciation? Biological Journal of the Linnean Society 95(1):3-16.

Mallet, J. 2008b. Wallace and the species concept of the early Darwinians. In: Natural Selection and Beyond: The Intellectual Legacy of Alfred Russell Wallace (Eds. Smith C. H. \& G. Beccaloni), pp. 102-113. Oxford University Press, Oxford.

Mallet, J. 2009a Darwin and Heliconius. URL: www. heliconius.org. http://heliconius.zoo.cam.ac.uk/ heliconius/2009/darwin-and-heliconius Accessed: November 9, 2009.

Mallet, J. 2009b. Why was Darwin's view of species rejected by $20^{\text {th }}$ Century biologists? Biology \& Philosophy (in press).

Mallet, J. \& M. JoRon, 1999. The evolution of diversity in warning colour and mimicry: polymorphisms, shifting balance, and speciation. Annual Review of Ecology and Systematics 30:201-233.

MAYr, E. 1942. Systematics and Origin of Species. Columbia University Press, New York.

MAYR, E. 1963. Animal Species and Evolution. Cambridge, Harvard University Press, Massachusetts.

MaYr, E. 1982. The Growth of Biological Thought. Diversity, Evolution, and Inheritance. Cambridge, Belknap, Massachusetts.

Müller, F. 1879 Ituna and Thyridia; a remarkable case of mimicry in butterflies. Proceedings of the Entomological Society of London 1879:xxxxix.

Poulton, E.B. 1904. What is a species? Proceedings of the Entomological Society of London 1903:lxxviicxvi.

Price, T. 2008. Speciation in Birds. Roberts \& Co, Greenwood Village.

Raia, P. \& S. Meiri, 2006. The island rule in large mammals: Paleontology meets ecology. Evolution 60(8):1731-1742.

RothschiLd, M. 1983. Dear Lord Rothschild. Birds, Butterflies and History. Hutchinson, London.

Rothschild, W. [\& JoRDAN, K.] 1895. A revision of the Papilios of the eastern hemisphere, exclusive of Africa. Novitates Zoologicae 2(3):167-463.

SCHLUTER, D. 2009. Evidence for ecological speciation and its alternative. Science 323(5915):737-741.

Schluter, D. \& L. M. Nagel, 1995. Parallel speciation by natural selection. The American Naturalist 146(2): 292-301.

Scott, J. A. 1986. Butterflies of North America. Stanford Univ. Press, Stanford.

Stresemann, E. 1975. Ornithology. From Aristotle to the Present. Harvard University Press, Cambridge, Massachusetts.

Tolman, T. \& R. Lewington, 1997. Butterflies of Britain and Europe. Harper Collins, London.

TRIMEN, R. 1869. On some remarkable mimetic analogies among African butterflies. Transactions of the Linnean Society of London 26:497-521. 
VAne-Wright, R. I. \& R. DE Jong, 2003. The butterflies of Sulawesi: annotated checklist for a critical island fauna. Zoologische Verhandelingen, Leiden 343:1-267.

Wallace, A. R. 1858 On the tendency of species to form varieties; and on the perpetuation of varieties and species by means of natural selection. III. On the tendency of varieties to depart indefinitely from the original type. Journal of the Proceedings of the Linnean Society of London 3:53-62.

Wallace, A. R. 1864. On the phenomena of variation and geographical distribution as illustrated by the
Malayan Papilionidae. The Reader 491-493.

Wallace, A. R. 1865. On the phenomena of variation and geographical distribution as illustrated by the Papilionidae of the Malayan region. Transactions of the Linnean Society of London 25:1-71.

Wallace, A. R. 1870. Contributions to the Theory of Natural Selection. A series of Essays. Macmillan, London.

Wallace, A. R. 1889. Darwinism. An Exposition of the Theory of Natural Selection with Some of its Applications. Macmillan \& Co., London.

Walsh, B. D. 1863. Notes by Benj. D. Walsh. Proceedings of the Entomological Society of Philadelphia 2:182-272. 